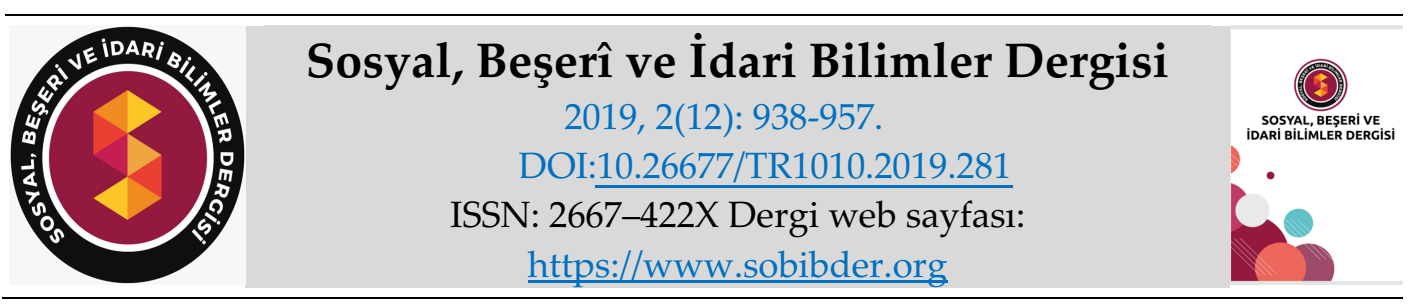

ARASTIRMA MAKALESI

\title{
İşletmelerde Kurumsallaşma Düzeyi ve Yönetim Bilişim Sistemleri İlişkisi
}

Alper DUYSAK, MSc. Gazi Üniversitesi, Bilişim Enstitüsü, Ankara, e-posta: alperdu90@gmail.com

ORCID: https://orcid.org/0000-0002-9850-9926

Öz

Bu çalışmanın amacı, işletmelerin kurumsallaşma düzeyi ile yönetim bilişim sistemleri kullanımı arasında bir ilişki olup olmadığını araştırmaktır. Bunun için \%90 güven aralığıyla gerçekleştirilen çalışma kapsamında Ankara ilinde, işletmeler arasında ayrım gözetmeksizin, 100 adet işletme yetkilisine demografik sorular, kurumsallaşma düzeyini ölçen sorular ve işletmede kullanılan yönetim bilişim sistemlerini tespit amaçlı sorular içeren üç bölümlü bir anket uygulanarak elde edilen veriler SPSS programı ile istatistiksel olarak analiz edilmiştir. Yapılan korelasyon testi sonucu, bu iki unsur arasında anlamlı ve direk yönlü bir ilişki tespit edilmiştir. Ortaya çıkan $r$ değeri 0,299 olup 0,2 ve 0,4 değerleri arasında yer almaktadır. Dolayısıyla bu ilişkinin zayıf bir ilişki olduğu yorumu yapılmıştır. Ayrıca işletmelerin kurumsallaşma düzeylerinin, faaliyet sektörüne veya faaliyet yılına göre farklılaşmazken çalışan sayısına veya ortaklık yapısına göre farklılaştığı gözlemlenmiştir. Bununla birlikte işletmelerin yönetim bilişim sistemleri kullanımının ise faaliyet sektörüne veya ortaklık yapısına göre farklılaşmazken faaliyet yılı veya çalışan sayısına göre farklılaştı̆̆ da tespit edilmiştir.

Anahtar Kelimeler: Kurumsallaşma, Kurumsallaşma Düzeyi, Yönetim Bilişim Sistemleri.

Makale Gönderme Tarihi: 09.10.2019

Makale Kabul Tarihi: 15.12.2019

\section{Önerilen Atıf:}

Duysak, A. (2019). İşletmelerde Kurumsallaşma Düzeyi ve Yönetim Bilişim Sistemleri İlişkisi, Sosyal, Beşeri ve İdari Bilimler Dergisi, 2(12): 938-957.

(c) 2019 Sosyal, Beşerî ve İdari Bilimler Dergisi. 


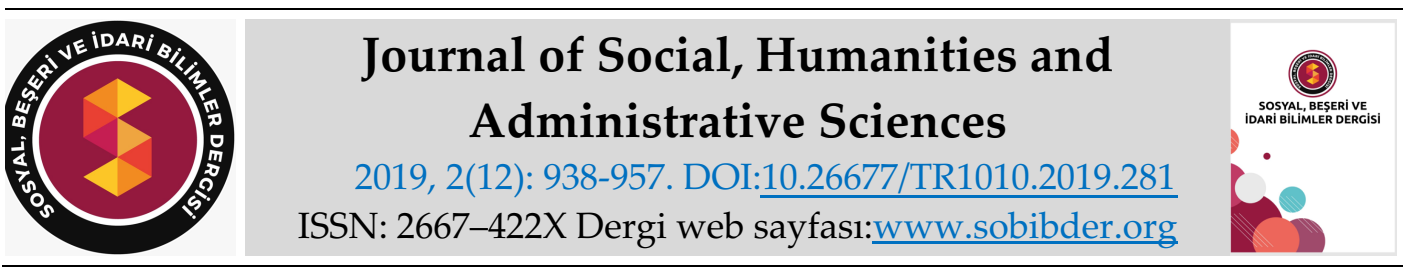

\title{
$\underline{\text { RESEARCH PAPER }}$
}

\section{Relationship Between the Level of Institutionalization and Management Information Systems in Businesses}

\author{
Alper DUYSAK, MSc. Gazi University, Informatics Institute, Ankara, e-mail: \\ alperdu90@gmail.com \\ ORCID: https://orcid.org/0000-0002-9850-9926
}

\begin{abstract}
The purpose of this research is to investigate if there is a relationship between the levels of institutionalization of businesses and their use of management information systems. For this purpose, within the scope of this study, which was implemented with $90 \%$ confidence interval, a threefold survey containing demographic questions, questions measuring the level of institutionalization, and questions aiming to determine the managament information systems used in the organisation was conducted with 100 business officials in Ankara without making a distincion between the organisations and the obtained data was analyzed statistically with SPSS program. As a result of the correlation test conducted, a significant and positive relationship was determined. The generated $r$ value is 0,299 and it is between the values of 0,2 and 0,4 . Therefore, the relationship was interpreted as a weak one. Besides, it was observed that whereas the levels of institutionalization of the businesses do not change according to activity sector or years of activity, they change according to number of employees or partnership structure. It was also observed that whereas business' use of management information systems do not change according to activity sector or partnership structure, they change according to years of activity or number of employees.
\end{abstract}

Keywords: Institutionalization, Level of Institutionalization, Management Information Systems. Received: 09.10.2019

Accepted: 15.12 .2019

Suggested Citation:

Duysak, A. (2019). Relationship Between the Level of Institutionalization and Management Information Systems in Businesses, Journal of Social, Humanities and Administrative Sciences, 2(12): 938-957.

(C) 2019 Sosyal, Beşerî ve İdari Bilimler Dergisi. 


\section{Gíriş}

Kurumsallaşma kavramı işletmeler için günümüzde çok önemli bir yere sahiptir. Çünkü kurumsallaşma; bir işletmenin, kendisini oluşturan kişilerden bağımsızlaşmasını ve böylece o işletmenin, kişilerin bireyselliklerinden etkilenmemesini sağlar. Böylece işletme, kendisi için belirlenen amaç ve hedefler doğrultusunda en verimli ilerlemeyi sağlayabilir. Kurumsal bir işletmede kararlar, belirlenen prensip ve kurallara göre, işletmenin çıarlarının kişilerin çıarlarından üstün tutulması esasına göre ve işletme için en iyisi hedeflenerek objektif bir biçimde alınır. Bu da işletmeyi, kişilerden kaynaklanabilecek olan duygusal kararlar, bencil tavırlar veya tamamen kötü niyetli, doğrudan işletmeyi hedef alan eylemler gibi işletmeye zarar verebilecek hatta onu iflasa götürebilecek olan durumlardan korur. Aynı zamanda kurumsallaşma, işletme için en iyi sonuçların alınmasını da sağlar. Kurumsallaşma, bu özellikleri sebebiyle işletmelerin sürdürülebilirliği ve başarısı adına önemli katklılar sunmaktadır. Rekabetin üst düzeyde yaşandığı ve hem ayakta kalmanın hem de başarılı bir işletme olmanın özellikle zorlaştığı günümüzde, işletmeye sağladığı bu katkılar, kurumsallaşmanın önemini gözler önüne sermektedir.

Kurumsallaşma, pek çok akademik çalışmaya konu olmuş bir kavramdır. Çeşitli araştırmacılar kurumsallaşmanın farklı yönlerini ele almış veya kurumsallaşmayı farklı kavramlarla birlikte inceleyerek farklı çalışmalar ortaya koymuştur. Örneğin; İşçi, Bal Taştan ve Kozal (2013) çalışmalarında örgütlerde kurumsallaşma düzeyinin nepotizm üzerindeki etkisini incelerken; Akyol ve Zengin (2014) turizmde kurumsallaşma sorunlarını konu edinmiştir. Derin ve Şimşek Ilkım ise (2016) çalışmalarında kurumsallaşmanın lider-üye etkileşimi ile olan ilişkisini ele almışlardır. Apaydın (2008) kavramın firma performansı ile olan ilişkisini incelerken; Yenice ve Dölen'in çalışmaları (2013) kurumsallaşma kavramının firma değeri ile olan ilişkisi üzerine olmuştur. Türkoğlu ve Çizel ise çalışmalarında (2016) kurumsallaşma ve rekabet gücü ilişkisini ele almışlardır. Kurumsallaşma kavramı, ayrıca, yoğun olarak aile işletmeleri ile ilişkilendirilerek de çalışılmıştır. Ural ve Balıkçıŏlu (2004), Yazıcıoğlu ve Koç (2009), Saral Kobal ve Aşkun Yıldırım (2016) kurumsallaşmayı bu şekilde ele alanlardan sadece birkaçıdır. Ancak kurumsallaşmanın, günümüzde işletmeler için giderek büyük önem kazanan yönetim bilişim sistemleri ile birlikte ele alınması konusunda literatür aynı zenginliği gösterememektedir.

Yönetim bilişim sistemleri (YBS) de kurumsallaşma gibi günümüzde işletmeler için önemli bir konuma sahiptir. Günümüzde tamamen bilgisayar destekli sistemler olan yönetim bilişim sistemleri, artık pek çok işletmede işleyişin ayrılmaz bir parçası konumundadır. Yönetim bilişim sistemleri, bir organizasyonun yönetim kademesine bilgi sağlayarak yönetimin karar vermesini kolaylaştıran bilgisayar destekli sistemlerdir. Söz konusu bilgiler; bilgisayar üzerinden sisteme veri girişinin yapılması sonrasında, bu verilerin kaydedilip önceden belirlenmiş prosedürlere göre işlenerek yönetim için anlamlı ve faydalı hale getirilmesi ile elde edilir ve düzenli veya isteğe göre oluşturulan raporlarla yönetime sunulur. YBS sistemlerinin sağladığı bilgiler, işletmenin içine veya dışına yönelik olabilir. İşletmenin içindeki farklı birimler kendine özgü YBS sistemleri kullanabileceği gibi organizasyonun tamamı bütüncül bir veya birkaç YBS sistemi de kullanabilir. $\mathrm{Bu}$ sistemlerin nasıl dizayn edileceği, hangi konularda ve hangi çapta bilgi üreteceği, hangi birimler tarafından nasıl kullanılacağı vb. konular, genellikle sisteme ihtiyaç duyan işletmenin ihtiyaçlarına yönelik olarak yöneticilerin yönlendirme ve onayı doğrultusunda sistem tasarımcısı rolünü üstlenen kişiler tarafından belirlenir ve daha sonra tasarlanan sistem veya sistemlerin yazılımsal tabanının bu alanda yetkin kişiler tarafından geliştirilmesiyle, söz konusu sistemler organizasyona entegre edilmek üzere hazır hale gelir. Değişen işletme ihtiyaçlarına göre yönetim bilişim sistemlerinin de güncellenmesi gerekebilmektedir. Bilgi çağının yaşandığ rekabet edebilmek ve en doğru kararları alabilmek için bilgiye çok fazla ihtiyaç duyduğu, "bilgi 
güçtür" sözünün çokça rağbet ve kabul gördüğü günümüzde, YBS'nin temel işlevinin bilgi üretmek olması, YBS'nin önemini açıkça göstermektedir.

Bu çalışmanın yapıldığı sırada, işletmeler için iki önemli kavram olan kurumsallaşma ve yönetim bilişim sistemlerinin ilişkisini araştırmaya yönelik daha önce yapılmış bir çalışmaya araştırmacı tarafından rastlanılmamıştır. Bu çalışmanın amacı, kurumsallaşma ve yönetim bilişim sistemlerinin ilişkisini araştırarak bu alana yönelik bir adım atmaktır. Bu durum, çalışmayı önemli kılmaktadır.

Çalışma evreni Ankara'daki işletmeler olarak belirlenmiştir. Çalışma kapsamında, işletmeler arasında herhangi bir ayrım gözetmeden, işletmelerin kurumsallık düzeyleri ile YBS kullanımları arasında bir ilişkinin olup olmadığı araştırılmış ve araştırma sonuçları yapılan istatistiksel çalışmaya göre yorumlanarak ortaya konulmuştur. Ayrıca araştırmanın ana amacıyla uyumlu bir biçimde; kurumsallaşma ve yönetim bilişim sistemlerinin, işletmelerin faaliyet gösterdiği sektör, faaliyet yılı, çalışan sayısı ve ortaklık yapısı olmak üzere başka unsurlarla ilişkili olup olmadıklarına dair saptama ve yorumlar da yapılmıştır. Bununla beraber, çalışma Ankara'daki işletmelerle sınırlı kalmıştır.

\section{KAVRAMSAL ÇERÇEVE}

\section{Kurumsallaşma}

Kurumsallaşma kavramı hakkında literatürde pek çok tanıma rastlamak mümkündür. Apaydın (2008:122), kurumsallaşma kavramı için, kararlı olmayan veya teknik eylem kapasitesi dar, organizasyonu gevşek olan yapıların, örgütsel istikrar, meşruluk, öngörülebilirlik, kaynakların artırılması ve çevreye uyum sağlama amacıyla, düzenli, kararlı ve sosyal olarak kurumsal çevreye entegre olmuş yapılar haline gelmeleri ve bu yeni durumun bütün çalışan ve yöneticiler tarafından aynı algı düzeyiyle ele alınıp benimsenmesi, sonuç olarak da farklı koşul ve ortamlara bağımlı olmaksızın, ortaya çıkan yeni yapının gerektirdiği davranış biçimlerinin otomatik olarak uygulanması biçiminde kapsamlı bir tanım yapmıştır. İşçi ve diğerleri (2013:61) ise kurumsallaşmanın; örgütlerin ilke, politika ve uygulamalarının kişilerden bağımsız olmasını ifade eden kavram olduğunu belirtmişlerdir. Cevher'e göre (2014:588) kurumsallaşma, örgütsel değişimi açıklama niteliğine sahip ve işletmelerin çevrelerine ayak uydurma yol ve yöntemlerini gösteren sistemsel bir olgudur. Nişancı, Oğrak, Kaya, Özçelik ve Düzgün (2015:176) tarafından yapılan bir başka tanım; kurumsallaşmayı bir süreç, nitelik veya örgütsel ve yönetsel bir değişim sonucu ortaya çıkan yapı veya düzen olarak ifade etmektedir. Narmambetova, Avci ve Barlı (2016:189), kurumsallaşmayı, bir işletmeyi sistemli bir yapıya kavuşturma, kişilerden ziyade belirli kural, standart ve prosedürlere göre işletmek üzere bir düzen meydana getirmek olarak ifade etmişlerdir. Kurumsallaşma, Aylan ve Koç tarafından (2017:564), işletmelerin, kendi varlıklarını, kişilerin varlıklarına bağımlı olmadan sürdürebilmeleri olarak tanımlanmıştır. Kalkan ise (2018:6) kurumsallaşmayı, bir işletmenin, özüne uygun kural, norm, standart ve prosedürlere sahip olması olarak ifade etmiştir.

Yapılan tanımlar incelendiğinde, örgütler için kurumsallaşma kavramı konusunda öne çıkan ortak noktalar; değişen çevreye uyum sağlamak, kişilerden bağımsız bir yapı haline gelerek standartlara sahip olmak ve bir süreç olmak şeklinde görünmektedir. Bu doğrultuda, kurumsallaşma için şöyle bir tanım da yapılabilir: Kurumsallaşma, bir örgütün çevreye uyum sağlamak için kişilerden bağımsız ve standartlara dayalı bir yapıya dönüşme sürecidir. 
Kurumsallaşma işletmeler için son derece önemli bir kavram durumundadır. Dolayısıyla kurumsallaşmanın ölçülmesi, bir işletmenin ne düzeyde kurumsal olduğunun belirlenmesi de önemlidir. Çünkü kurumsallaşmak isteyen işletmeler, kurumsallaşma süreçlerini tamamlamak için doğru adımları ancak mevcut kurumsallaşma düzeylerini tespit ettikten sonra belirleyebilirler. Kurumsallaşmanın bilimsel bir kesinlikle tespit edilebilmesi için ise bazı örgütsel ve yönetsel kriterlerin ortaya konması ve işletmelerin bunları ne düzeyde gerçekleştirdiğinin belirlenmesi gerekir. İşletmelerde kurumsallaşmanın olup olmadığı veya kurumsallaşma düzeyinin ne olduğu, bir takım evrensel kriterlerle belirlenmektedir. Bu kriterler, literatürde kurumsallaşma göstergeleri olarak ifade edilmektedir. Kurumsallaşma göstergeleri şunlardır (Aylan ve Koç, 2017:567): İşletme anayasası, Formel örgüt yapısı, stratejik planlama süreci, profesyonelleşme, yetki devri ve yetkilendirme, yönetim anlayışı ve yönetime katılma, karar alma şekli, etkin iletişim sistemi, iç denetim faaliyetleri. Söz konusu kriterler, kısaca şu şekilde açılanabilir:

\section{Işletme Anayasası}

İşletme anayasası, iş ve işleyişle ilgili bütün prensip ve kuralların yazılı olarak ortaya konduğu temel bir rehber, bir yol göstericidir. İşletme anayasasında işletmenin vizyonu, misyonu, genel ve özel hedefleri yer alır. Belirlenen bütün prensip ve kurallar, oluşabilecek sorunlara ilişkin genel bir çerçeve sunmalıdır. İşletme anayasası, tüm işletmeler için kurumsallaşmanın önemli bir göstergesi olarak kabul edilmektedir (Yazıcıŏglu ve Koç, 2009:500). İşletme anayasası, kurumun işleyişinin bir parçası olan bütün süreçlere dair yazılı kuralları içerir (Narmambetova ve diğerleri, 2016:190).

\section{Formel Örgüt Yapısı}

Örgüt yapısı, kurumsallaşmayı etkileyen unsurlardandır. Örgüt kültürüne olumlu veya olumsuz etkileri olabilen örgüt yapısının niteliğine göre örgüt kültürünün pasif ya da kavgacı olması da söz konusudur. Örgüt yapısı, işletme içinde gerilim ve çatışmaları azaltmada ve iş performansını arttırmakta etkili olabilir (Şahman, Tengilimoğlu ve Işık, 2008:8).

\section{Stratejik Planlama Süreci}

Stratejik planlama olmadan örgütlerin sürdürülebilir bir rekabet üstünlügüne sahip olması mümkün olmamaktadır. Stratejik planlama süreci, işletmenin tüm paydaşlarının katılımını gerektirir. Ayrıca stratejik plan, sadece bir kez yapılan ve böylece tamamlanan bir plan da değildir. (Demir ve Yılmaz, 2010:70). Dolayısıyla örgütlerin daima stratejik planlama süreci içinde olması gerekir.

\section{Profesyonelleşme}

Kurumsallaşma, profesyonel yönetimin temelini oluşturur ve böylece daha sistemli, daha kaliteli, daha bilinçli bir işletme yönetimi var olabilir (Kalkan, 2018:13). Profesyonel yönetilen bir işletmede profesyonel yöneticiler de olmalıdır. Profesyonel yöneticiler, yöneticilik işini meslek olarak icra eden, kar ve riski başkalarına ait olmak üzere ürün ortaya koymak için örgüt kaynaklarını örgüt amaçları doğrultusunda kullanma yetkisi olan kişilerdir. Profesyonel yöneticiler, orta ve uzun vadeli planlamalar yapar, nedenler ve sonuçlar arasındaki bağlantıları araştırıp belirler (Yıldırım, 2019:582). İşletmeler, bünyesindeki profesyoneller sayesinde diğer işletmelerdeki değişimi takip edebilmektedirler. Profesyonel çevreye entegre olan işletmeler, çevresel değişimlere daha iyi tepki verebilmektedirler (Apaydın, 2008:124). 


\section{Yetki Devri ve Yetkilendirme}

Yetki devri de bir yöneticinin elinde tutmakta olduğu karar verme yetkisini belirli şartlar dahilinde astına devretmesi olarak tanımlanabilir. Yönetici, karar verme yetkisini geçici olarak astına devredebilir ancak bu durumda astların verdiği kararlardan da yine kendisi sorumludur. Yönetici, yetkisini tekrar geri alabilir (Karavardar, 2011:162). Yetki devri, astların motivasyonu, kararların örgütteki benimsenme derecesi, yöneticilerin planlama, denetleme ve örgütü temsil etme gibi görevlere daha fazla vakit ayırabilmeleri ve astların, üst makamların faaliyetlerini daha çabuk öğrenmeleri konularında çok önemli ve olumlu bir role sahiptir. Dolayısıyla yöneticiler, yetki devrine bir gereklilik seviyesinde başvurmalıdırlar (Derdiman ve Uysal, 2014:270).

\section{Yönetim Anlayışı ve Yönetime Katılma}

Kurumsallaşma sürecinin doğal bir sonucu olarak örgütlerin demokratik ve katılımcı bir yönetim yapısına geçişi tüm çalışanların işletme süreçlerine dahil olarak sonuçlardan sorumluluk hissetmelerini sağlar. Sonuçta, çalışanlar işletmenin amaç ve hedeflerini benimser ve bu doğrultuda tutum ve davranışlar sergilerler (Yazıcıŏglu ve Koç, 2009:501).

\section{Karar Alma Şekli}

Bir işletme için etkili kararlar alabilmek işletmenin hayatta kalabilmesi açısından son derece önemlidir. Karar alma, bir başlangıç noktasına sahip ve bir seçimle sonlanan, bu iki nokta arasında da farklı düşünce, iş ve faaliyetlerin birbirini izlediği süreçtir. Kurumsallaşma sürecine girmemiş işletmelerde karar alma, plansız ve otokratik bir tarz ile işler. Ayrıca kararlar genellikle işletmeyi kuran şahısların hakim ve etkin olduğu bir ortamda alınır. Oysa kurumsallaşma, kararların katılımcı bir yöntem ile alınmasını, alınacak kararların uygulayıcılarının da sürece dahil olmasını gerektirir. Karar alınırken de işletmenin içinde bulunduğu ortamın şartları bilinmeli ve bu şartlar, iyi bir şekilde takip edilmelidir (Aylan ve Koç, 2017:572).

\section{Etkin İletişim Sistemi}

İşletmelerin kurumsal bir yapıda olmaları çok yönlü ve sürekli bir iletişim sistemine yani etkin bir iletişim sistemine sahip olmayı gerektirir (Karavardar, 2011:163). Etkin örgütsel iletişim, günümüzde küreselleşen dünyadaki yoğun rekabet ortamında açık, şeffaf, sürekli gelişme ve değişme arzusunda olan ve yönetim politikalarını geliştiren işletmelerin başarısının anahtarıdır. Örgütsel iletişimin önemi, örgütlerin büyümesi sonucu yönetimin karmaşıklaşması, uzmanlaşmanın artması ve teknolojik gelişmeler gibi unsurlara paralel olarak giderek artmıştır. Örgüt içi iletişim kalitesinin, örgütün başarısını etkilemesinin yanında çalışanların psikolojileri üzerinde de önemli olduğu düşünülmektedir. İletişimin yeterince etkin omlaması sonucu motivasyonları azalan çalışanların psikolojik olarak olumsuz etkilendikleri bilinmektedir (Tinaztepe, 2012:54).

\section{İç Denetim Faaliyetleri}

Hesap verebilirlik olarak da ifade edilen iç denetim; işletme içindeki kişi veya birimlerin, belirli bir yetki kullanma, karar verme, iş ve faaliyette bulunma gibi eylemlerinden sorumlu tutulabilmeleri ve bu alanlarda onlardan açıllama talep edilebilmesidir (Aylan ve Koç, 2017:573).

İşletmelerde kurumsallaşmanın olup olmadığı veya kurumsallaşma düzeyinin ne olduğu, söz konusu kriterlere işletmede ne ölçüde uyulduğunun tespiti ile anlaşılabilmektedir. Bu tespit yapıldıktan sonra kurumsallaşma düzeyini arttırmaya yönelik adımlar planlanıp atılabilir. 


\section{YÖNETIM BİLIŞSIM SISTEMLERI}

Yönetim kavramı, geniş bir anlam taşımaktadır. Bu geniş anlam çerçevesinde insan yönetimi, para yönetimi, bilgi yönetimi gibi örnekler verilebilir. Hemen hemen her şeyin yönetiminden bahsetmek mümkündür. Dolayısıyla yönetim kavramının bütün bilim dalları ile ilişkisi olduğu söylenebilir (Anameriç, 2005:26). Bununla birlikte yönetim, her zaman bir karar alma işlemidir (Emhan, 2007:212). Organizasyonlar açısından bakıldığında ise; yönetim, belirli amaçlar doğrultusunda kaynakların ve çalışanların uyumlu biçimde bir araya getirilerek düzenle işletilmesidir (Kalıpsız, 1989:102). İşletmeler, yönetim kapsamındaki planlama, örgütleme, yönlendirme, koordinasyon ve kontrol faaliyetleri ile organizasyonlarının; amaç ve hedeflerini belirler, amaç ve hedeflere ulaşmak için gerekli kaynakları temin eder, iş tanımlarını, görev dağılımlarını, yetki ve sorumlulukları belirler, tüm faaliyetleri amaç ve hedeflere yönlendirir, işletme faaliyetleri arasında uyum veya koordinasyon sağlar, faaliyetlerin sonucu olarak amaç ve hedeflere ne kadar ulaşıldığını tespit eder, amaç ve hedeflerden sapmalar varsa gerekli tedbirleri alır (Tanyıldızı ve Demir, 2019: 20).

Bilgi sistemleri olarak da ifade edilen bilişim sistemleri ise genel anlamda el ile yapılan iş ve işlemleri otomatik olarak gerçekleştiren bilgisayar tabanlı sistemlerdir. Mevcut bilgiler sisteme girildiğinde, bu bilgiler sistem tarafından çeşitli programlar aracılı̆̆ıyla işleme tabi tutularak gerekli hesaplama veya düzenlemeler yapılır. Bu hesaplama ve düzenlemeler sonucunda ise sistem, kullanıma sunmak üzere çıtılar ve raporlar hazırlar (Miman, Yoğun ve Önel, 2016:161). Bilişim sistemleri, işletmelerin çevrelerindeki değişiklikleri algılamalarında ve onların çevrelerine göre eylemde bulunmalarına yardımcı olan bir role sahiptir. Bilişim sistemleri, çevreyi tarama ve organizasyonel bir eylem gerektirebilecek dış değişimlerin tespit edilmesinde yöneticilere yardım etme konusunda anahtar durumunda olan araçlardır (Laudon ve Laudon, 2012:86).

Yönetim bilişim sistemleri de işletmelerde kullanılan yönetim odaklı bilişim sistemleridir. Emhan (2007:221), yönetim bilişim sistemlerini, bir organizasyonun yönetiminde kullanılan bilgilerin işlenerek gerekli yerlere zamanında ve doğru olarak iletilmesini sağlayan sistemler olarak tanımlamıştır. Al-Mamary ve diğerlerine göre (2014:1284) YBS, tüm kademeden yöneticilerin, sorumlu oldukları alanlarda zamanında ve etkili kararlar verebilmeleri için, verileri enformasyona dönüştürerek kullanıma sunan sistemlerdir. Surwade (2016:201), yönetim bilişim sistemlerinin, bir organizasyonun bölümlerini düzenlemek, değerlendirmek ve etkin biçimde yönetmek adına yönetime çeşitli araçlar sağlayan bilgisayar temelli sistemler olduklarını ifade etmiştir. Miman ve diğerleri (2016:161) ise işletmenin amaçları göz önüne alınarak üst düzeyden alt düzeye doğru yönetimin ihtiyaçlarını karşılamaya yönelik geliştirilen, donanım ve yazılımdan oluşan her türlü sistemin bir yönetim bilişim sistemi olduğunu ifade etmiştir. Yönetim bilişim sistemleri hakkında literatürde daha pek çok tanım bulunmaktadır. Yukarıda yer verilen tanımlamalar, kavramı genel olarak açılamak için yeterlidir.

Bu tanımları dikkate alarak şöyle bir tanım da yapılabilir: Yönetim bilişim sistemleri, bir organizasyondaki yönetim faaliyetlerine yönelik bilişim ihtiyacını karşılamak için geliştirilen bilgisayar tabanlı sistemlerdir. Bu tanımın farklı yönlerini aşağıdaki gibi açıklamak mümkündür:

YBS'nin yönetim faaliyetlerine yönelik bilişim sağlar. Bu durum, yönetim kavramının özünde yer alan karar verme eylemi ile ilgilidir. Yöneticiler, sahip oldukları bilgileri değerlendirerek karar verirler. Yanlış veya eksik bilgiye sahip olmak, yönetici çok nitelikli olsa bile genellile yanlış kararlar vermeye sebep olur. Çünkü, doğru kararlar verebilmek için doğru karar verme becerisi tek başına yeterli değildir. Bu beceriyi, gerekli bilgi ile beslemek gerekir. Çok iyi bir arabanın, 
deposuna yakıt konulmadığı zaman çalışmaması veya kendisine uygun olmayan bir yakıt konulduğunda, performansında ve mekanizmalarında ciddi sorunlar yaşanması gibi yönetici de nitelikli, doğru, yeterli ve zamanında sağlanan bilgi ile beslenmelidir. Yönetici, ancak o zaman yönetim becerilerini iyi bir performansla sergileyebilir. İşte YBS de işletme yönetimine bu nitelikteki bilgileri sunarak destek olmaktadır.

YBS, bilişim ihtiyacını, bir süreç kapsamında karşılar. Söz konusu bilişim süreci, YBS'yi geliştiren ve kullanan insanların katkıları ve katılımları ile gerçekleştirilen bir süreç olup verilerin organizasyon içindeki veya dışındaki kaynaklardan, önceden belirlenmiş prosedürlere göre toplanması, kaydedilmesi ve işlenmesi ile bilgiye dönüştürülerek yönetimin çeşitli kademelerine sunulması sürecini ifade eder. Verilerin toplanma ve işlenme biçimini belirleyen prosedürler, YBS'yi geliştiren teknik kişiler tarafından, yöneticilerin ve kullanıcıların ihtiyaçları doğrultusunda, genellikle onların da görüşlerini alarak belirlenir. Yöneticilerin, diğer kullanıciların veya YBS'den sorumlu teknik kişilerin içinde bulunduğu ve bu sürecin bir parçası niteliğinde olan geri besleme kapsamında, bu prosedürlerde geliştirme ve güncellemeler yapilabilmektedir.

Yönetim bilişim sistemleri, bilgisayar tabanlı sistemlerdir. Bu durum, bilişim ihtiyaçlarını karşılama konusunda bilgisayarların sağladığı çok önemli avantajların bir sonucudur. Bu avantajların bazıları, verilerin aynı anda pek çok kaynaktan toplanabilmesi, hatasız ve büyük miktarlarda kaydedilebilmesi, bilgisayarların yüksek işlem hızı ve kapasitesi sayesinde verilerin çok hızlı ve farklı biçimlerde işlenerek bilgiye dönüştürülebilmesini kapsamaktadır. Kısaca verilerin toplanarak bilgiye dönüştürülmesi ve söz konusu bilgilerin tek yönlü veya karşılıklı aktarımı olarak ifade edebileceğimiz bilişim, bilgisayarlar olmadan da mümkündür ancak bilişim sağlanırken bilgisayarların olmaması çok daha düşük bir verimliliğe sebep olur. Zaten bilgisayarların gelişerek günümüzde bilişim sistemlerinin tabanı haline gelmiş olmaları, nitelikli bilişim ihtiyacının ve bilgisayarların bilişim performansında sağladığı devasa artışın bir sonucudur. Dolayısıyla, günümüzde bilgisayarsız bir bilişim sistemi düşünülemeyeceği gibi böyle bir YBS de düşünülemez. Bu yüzden yönetim bilişim sistemleri, bilgisayar tabanlı sistemler olarak varlıklarını sürdürmektedir.

$\mathrm{Bu}$ nitelikleri sebebiyle YBS, günümüzde işletmelerde yaygın olarak kullanılmaktadır. İşletmelerin kullandığı yönetim bilişim sistemleri, işletmeden işletmeye farklılık göstermektedir. $\mathrm{Bu}$ durum, işletmelerdeki çeşitli özelliklerin farklı olmasından kaynaklıdır. Tüm modern organizasyonların belirli özellikleri vardır. Bu organizasyonlar, iş gücü ve uzmanlaşmanın açık ve net bölümlendirildiği bürokratik yapılardır ve uzmanların organizasyondaki yerini; herkesin bir başkasına hesap verebilir olduğu bir otorite hiyerarşisi içerisinde düzenlerler. Otorite, soyut kural veya prosedürlerle belirlenmiş eylemlerle sınırlı iken söz konusu kurallar da tarafsız ve evrensel bir karar verme sistemi oluşturur. Organizasyonlar bu durumda çalışanları kişisel bağlantılara göre değil teknik yeterlilik ve profesyonelliği baz alarak işe almaya ve terfi ettirmeye çalışır. Organizasyon, kısıtlı girdi ile çıktıyı azami ölçüye çıkarmak olarak ifade edilebilecek verimlilik prensibine bağlıdır. İş süreçleri, işletme kültürü, işletme politikaları, çevre, yapı, amaçlar, müşteriler ve liderlik tarzı da organizasyon özellikleridir. Tüm bu özellikler, işletmeler tarafından ne tür bilişim sistemleri kullanıldığını etkiler (Laudon ve Laudon, 2012:84). Bütün organizasyonlar, bir yapı veya biçime sahiptir. Bir işletmede bulunabilecek yönetim bilişim sistemleri, genellikle organizasyonel yapıyı yansıtır. Örneğin, bir hastane gibi profesyonel bir bürokraside, yönetim, doktorlar ve hemşire ve sosyal hizmet uzmanları gibi profesyonel personel tarafından kullanılan paralel hasta kayıt sistemleri ile karşılaşmak sıra dışı bir durum değildir. Küçük girişimci işletmelerde ise genellikle acele içinde yetersiz şekilde geliştirilmiş sistemler bulunur. Yüzlerce bölgede faaliyet gösteren çok departmanlı dev işletmelerde ise yaygın olarak 
birleştirici tek bir bilişim sistemi yerine her bölümün kendi bilişim sistemleri takımı ile karşılaşılır (Laudon ve Laudon, 2012:88). Bir işletme, standart olarak piyasaya sunulan yönetim bilişim sistemlerini kullanabileceği gibi tamamen kendine özgü bir sistem veya sistemler de üretebilir. Benzer şekilde, bazı faaliyetlerinde yaygın olarak kullanılan sistemlerden yararlanabileceği gibi bazı faaliyetleri için kendine özgü sistemler de kullanabilir. İşletmelerin kullandığı çeşitli YBS uygulamaları; muhasebe ve finans yönetimi, insan kaynakları yönetimi ve maaş çizelgesi, müşteri ilişkileri yönetimi, karar destek, iş zekası, bilgi yönetimi, envanter yönetimi, e-ticaret ve internet satışları, internet tabanlı müşteri desteği, tesis yönetimi ve üretim operasyonları gibi işletme operasyonlarını destekleyebilir (Surwade, 2016:202).

\section{YÖNTEM}

\section{Evren ve Örneklem}

Çalışmanın evreni Ankara'daki işletmeler olarak belirlenmiş olup işletmeler arasında sektör, faaliyet alanı vb. herhangi bir ayrım gözetilmemiştir. Ankara İSİG Meclisi'ne göre Ankara'da 2018 yılı itibariyle 141823 işletme bulunmaktadır (http://www.guvenlicalisma.org). Bu sayı, işletmenin evrenini oluşturmaktadır. Çalışmanın örnekleminde yer alan işletmeler, basit tesadüfi örnekleme ile belirlenen 100 adet işletmeden oluşmaktadır ve çalışma \%10 hata payı ile, bir diğer deyişle, \%90 güven aralığında gerçekleştirilmiştir. Singh ve Masuku (2014) ve Israel (2013)'in çalışmalarında belirttiği üzere, bu çalışmada kullanılan örneklem büyüklüğü ifade edilen güven aralığ1 için istatistiksel olarak yeterli olmaktadır.

\section{Verilerin Toplanması}

Çalışma kapsamında toplanan veri, örneklemi oluşturan işletme yetkililerine anket uygulanması ile elde edilmiştir. Söz konusu anket formu üç bölümden oluşmakta olup ilk bölümde; işletmenin faaliyet gösterdiği sektör, işletmenin faaliyet yılı, işletmenin çalışan sayısı ve işletmenin ortaklık yapısını konu alan demografik sorulara yer verilmiştir. İkinci bölüm, işletmelerin kurumsallaşma düzeyini tespit amacını taşımaktadır. Bu bölümde, Aylan ve Koç tarafından (2017) ortaya konulan kurumsallaşma kriterleri ölçeği kullanılmıştır. Söz konusu ölçek, kurumsallaşma kriterlerini; İşletme Anayasası, Profesyonelleşme, Formel Örgüt Yapısı, Yetki Devri ve Yetkilendirme, Stratejik Planlama Süreci, Yönetim Anlayışı ve Yönetime Katılma, Karar Alma Şekli, Etkin Bir İletişim Sisteminin Oluşturulması ve İç Denetim Faaliyetleri (Hesap Verebilirlik) olmak üzere dokuz adet olarak ve toplam kırk sekiz açıklayıcı ifade ile ortaya koymuştur. Anket uygulamasında, katılımcıların bu açıklayıcı ifadeleri beşli likert ölçeği kapsamında değerlendirmeleri sağlanmıştır.

Üçüncü ve son bölümde ise işletmelerin kullandıkları YBS sistemlerinin tespiti amaçlanmış olup buna yönelik bir YBS listesi hazırlanmıştır. Bunun için yaygın olan YBS sistemleri araştırmacı tarafından araştırılmış, 26 başlık altında toplanarak listelenmiş ve katılımcılardan işletmede kullanılan sistemleri işaretlemeleri istenmiştir. Ayrıca, işletmede bunlar dışında başka bir YBS sistemi kullanılıyorsa "Diğer" seçeneği ile belirtilmesi ve işletmede hiçbir YBS sistemi kullanılmıyorsa "Hiçbiri yok" seçeneğini işaretlemeleri istenmiştir. Listede yer alan YBS sistemleri şunlardır: Araç Takip Sistemi, Bakım Yönetim Sistemi, Bütçe Yönetim Sistemi, Dış Ticaret Yönetim Sistemi, E-Ticaret Yönetim Sistemi, Finans ve Muhasebe Sistemi, İçerik Yönetim Sistemi, İnsan Kaynakları Yönetim Sistemi, İş Akış Yönetimi Sistemi, İş Sağlığı Güvenliği Sistemi, 
Kalite Yönetimi Sistemi, Kurumsal Performans Bilgi Sistemi, Müşteri Deneyim Yönetimi Sistemi, Müşteri Hizmetleri Yönetim Sistemi, Müşteri İlişkileri Yönetim Sistemi, Proje Portföy Yönetim Sistemi, Risk Yönetim Sistemi, Sabit Kıymetler Yönetimi Sistemi, Satınalma Yönetimi Sistemi, Satış Sonrası Hizmetler Yönetimi Sistemi, Satış ve Pazarlama Sistemi, Satış ve Talep Yönetim Sistemi, Sipariş Takip Sistemi, Stok ve Envanter Yönetim Sistemi, Tedarik Zinciri Yönetim Sistemi, Üretim Yönetim Sistemi.

\section{Verilerin Analizi}

Anket formları ile elde edilen veriler, istatistiksel olarak analiz edilmiş olup verilerin analizinde SPSS (Statistical Package for the Social Sciences) programı kullanılmıştır. Araştırmanın amaçları doğrultusunda frekans tabloları incelenmiş, bağımsız örneklem için t-testi, Oneway Anova analizleri ve Pearson Korelasyon analizi yapılmıştır. Analiz safhasında, temel olarak işletmelerin kurumsallaşma düzeyi ile kullandıkları YBS sayısından hareketle, işletmelerde kurumsallaşma ve YBS arasında bir ilişki olup olmadığı değerlendirilmiştir. Kurumsallaşma ve yönetim bilişim sistemlerinin, işletmelerin faaliyet gösterdiği sektör, faaliyet yılı, çalışan sayısı ve ortaklık yapısı olmak üzere başka unsurlarla ilişkili olup olmadıklarına dair saptama ve yorumlar da yapılmıştır.

\section{BULGULAR}

Toplanan verilerin analizi yapılırken öncelikle demografik verilerden hareketle frekans tabloları oluşturulmuş ve yorumlanmıştır. Daha sonra ise bağımsız örneklem t-testi ve tek yönlü Anova analizinden yararlanarak kurumsallaşma düzeyi ve yönetim bilişim sistemleri kullanımının sektöre, faaliyet yılına, çalışan sayısına ve ortaklık yapısına göre farklılaşıp farklılaşmadığı tespit edilmiş ve son olarak araştırmanın asıl konusu olan işletmelerin kurumsallaşma düzeyi ile yönetim bilişim sistemleri kullanımları arasında bir ilişki olup olmadığı korelasyon analizi yapılarak ortaya konumuştur. İşletme yetkilileri ile yapılan anketler sonucu toplanan verilerin tanımlayıcı istatistikleri şöyledir:

Tablo 1. Araştırmaya Katılan İşletmelerin Sektörel ve Faaliyet Yılı Dağılımı

\begin{tabular}{|l|c|c|}
\hline Sektör & $\mathbf{n}$ & $\mathbf{\%}$ \\
\hline Hizmet & 75 & 75 \\
\hline Üretim & 25 & 25 \\
\hline Toplam & 100 & 100 \\
\hline Faaliyet Yılı & $\mathbf{n}$ & $\mathbf{\%}$ \\
\hline $\mathbf{1 - 5}$ yıl & 32 & 32 \\
\hline $\mathbf{6 - 1 0}$ yıl & 12 & 12 \\
\hline $\mathbf{1 1}$ yıl ve üzeri & 56 & 56 \\
\hline Toplam & 100 & 100 \\
\hline
\end{tabular}

Tablo 1'de görüldüğü üzere; işletmelerin sektörel dağılımı incelenirken iki temel alan olan hizmet ve üretime göre dağılıma bakılmıştır. Araştırmaya katılan yüz işletmenin yetmiş beşi hizmet 
sektöründe faaliyet göstermektedir. Bu sayı, örneklemin \%75'ini temsil etmektedir. Üretim sektöründe faaliyet gösteren işletmelerin sayısı ise yirmi beş olup örneklemin \%25'ini ifade etmektedir. Dolayısıyla çalışmaya katılan işletmelerin çoğunluğu hizmet sektöründe faaliyet göstermektedir. Türk Mühendis ve Mimar Odaları Birliği'ne göre (https://www.tmmob.org.tr) 2017 yılında Türkiye' de toplam 2.892.670 KOBİ işletme bulunmakta ve bunların 372.600'ü imalat, bir diğer deyişle, üretim sektöründe faaliyet göstermektedir. Buradan hareketle Türkiye' de KOBİ ölçeğinde üretim işletmelerinin sayısının hizmet işletmelerine göre oldukça az olduğu söylenebilir. Çalışma KOBİ'lerle sınırlı olmamasına rağmen Tablo 1'de de benzer bir durum görülmektedir.

Araştırmaya katılan işletmelerin faaliyet yılı dağılımı da Tablo 1'de gösterilmiştir. Buna göre yüz işletmenin otuz ikisi 1-5 yıldır faaliyet göstermekte olup bu sayı örneklemin \%32'sini temsil etmektedir. On iki işletme 6-10 yıldır faaliyet göstermektedir ve bu grup çalışmaya katılan işletmelerin \%12'sini ifade etmektedir. Elli altı işletme de 11 yıl veya daha uzun süredir faaliyette olup \%56'ya karşılık gelmektedir. Görüldüğü üzere çalışmaya katılan işletmelerin yarıdan fazlası uzun süredir faaliyette olan işletmelerdir.

Tablo 2. Araştırmaya Katılan İşletmelerin Çalışan Sayısı ve Ortaklık Yapısı Dağılımı

\begin{tabular}{|l|c|c|}
\hline Çalışan Sayısı & $\mathbf{n}$ & $\mathbf{\%}$ \\
\hline 1-9 kişi & 29 & 29 \\
\hline 10-49 kişi & 27 & 27 \\
\hline $\mathbf{5 0 - 2 4 9}$ kişi & 21 & 21 \\
\hline 250 ve üstü & 23 & 23 \\
\hline Toplam & 100 & 100 \\
\hline Ortaklık Yapısı & $\mathbf{n}$ & $\mathbf{\%}$ \\
\hline Tek ortaklı işletme & 35 & 35 \\
\hline Çok ortaklı işletme & 45 & 45 \\
\hline Aile işletmesi & 20 & 20 \\
\hline Toplam & 100 & 100 \\
\hline
\end{tabular}

Araştırmaya katılan işletmelerin çalışan sayıları dağılımı Tablo 2'de gösterilmiştir. Çalışan sayılarının gruplandırılmasında, 2005/9617 numaralı Bakanlar Kurulu Kararı ile ortaya konulan “Küçük ve Orta Büyüklükteki İşletmelerin Tanımı, Nitelikleri ve Sınıflandırılması Hakkında Yönetmelik" temel alınmıştır. Görüldügüü üzere, yüz işletmeden 1-9 çalışanı olan işletme sayısı yirmi dokuz (\%29), 10-49 çalışanı olan işletme sayısı yirmi yedi (\%27), 50-249 çalışanı olan işletme sayısı yirmi bir (\%21) ve 250 veya daha fazla çalışanı olan işletme sayısı yirmi üçtür (\%23). Çalışmaya katılan işletmelerin, çalışan sayısı bakımından birbirine yakın olduğu görülmektedir.

Tablo 2, araştırmaya katılan işletmelerin ortaklık yapısını da göstermektedir. Bu bölümde, işletmeler, tek ortaklı, çok ortaklı ve ayrı bir kategori olarak aile işletmesi olarak ele alınmıştır. Görüldügü üzere otuz beş işletme, tek ortaklıdır. Bu sayı örneklemin \%35'ine karşılık gelmektedir. Çok ortaklı işletmelerin sayısı ise kırk beş olup örneklemin \%45'ini, bu işletmeler oluşturmaktadır. Aile işletmeleri ise yirmi adettir ve örneklemin $\% 20$ 'sini temsil etmektedir. Çalışmaya katılan işletmeler arasında en çok görülen ortaklık yapısı çok ortaklılık olup aile işletmeleri ise bu bakımdan sayıca en küçük gruptur. 
Kurumsallaşma ve YBS sistemlerinin; işletmelerin faaliyet gösterdiği sektöre, faaliyet yılına, çalışan sayısına ve ortaklık yapısına göre farklılaşıp farklılaşmadığını tespit etmek için bağımsız örneklem t-testi ve tek yönlü Anova testlerinden faydalanılmıştır.

Tablo 3. Kurumsallaşma ve YBS Sistemlerinin Sektöre Göre Durumu

\begin{tabular}{|l|l|c|c|c|c|c|}
\hline & Sektör & Say1 & Ortalama & Standart Sapma & $\mathbf{t}$ & $\mathbf{p}$ \\
\hline \multirow{2}{*}{$\begin{array}{l}\text { Kurumsallaşma } \\
\text { düzeyi }\end{array}$} & Hizmet & 75 & 3,2219 & 0,89192 & & \\
\cline { 1 - 6 } YBS sayıs1 & Üretim & 25 & 3,3092 & 0,83228 & $-0,430$ & 0,668 \\
\hline & Hizmet & 75 & 5,8000 & 6,02921 & & \\
& Üretim & 25 & 7,1600 & 6,04621 & \multirow{2}{*}{$-0,976$} & 0,331 \\
\hline
\end{tabular}

Kurumsallaşma ve YBS sistemlerinin sektöre göre durumunu tespit amaçlı yapılan bağımsız örneklem t-testi sonuçlarının gösterildiği Tablo 3'e göre, $\mathrm{p}$ değerleri kurumsallaşma ve YBS sayısı için 0,05 değerinden oldukça büyüktür. Dolayısıyla işletmelerin hizmet sektöründe veya üretim sektöründe olmaları ile kurumsallaşmaları arasında bir ilişki olmadığı görülmektedir. Aynı şekilde işletmelerin hangi sektörde olduğu YBS sayısı ile de ilişki göstermemektedir. Dolayısıyla faaliyet sektörünün bir işletmenin kurumsallaşma düzeyi veya YBS kullanımını etkilemediği görülmektedir. Öyleyse hem kurumsallaşma düzeyi hem de YBS kullanımı, sektörel farklılıkları aşan ve bir işletmeyi ilgilendiren genel konulardır, denebilir. Ayrıca, işletmelerin kurumsallaşma kavramına veya YBS kullanımına bakış açılarını belirlerken veya bu unsurları önemseme derecelerine karar verirken sektörel dinamikleri aşan bir değerlendirme yapmaları gerektiği de ortaya çıkmaktadır.

Kurumsallaşma ve YBS sistemlerinin faaliyet yılına göre durumunu tespit amaçlı yapılan tek yönlü Anova analizinin sonuçlarının gösterildiği Tablo 4'e göre, kurumsallaşma için p değeri 0,05'in oldukça üstündedir. Bu durum, işletmenin faaliyet yılının, işletmenin kurumsallaşma düzeyinde bir farklılaşmaya sebep olmadığını gösterir. Buradan hareketle, kurumsallaşmanın, eski veya köklü işletmelerde daha ileri düzeyde olacağı yönünde bir yorumun yanlış olacağ anlaşılmaktadır. Benzer şekilde, yeni işletmelerin kurumsallaşmaya daha çok önem vererek daha kurumsal oldukları gibi bir yorum da dayanaksız görünmektedir. Kurumsallaşma, işletmenin işleyişine ilişkin temel bir anlayış ve yaklaşım biçimi niteliği taşıdığından, işletmenin kurumsallık düzeyi, yöneticilerin vizyon ve uygulamalarına bağlı olarak belirlenmektedir. Yöneticilerin bu tavır ve tutumları da işletmenin yaşı ile ilgili değildir. Köklü bir işletmede kurumsallaşma vizyonu taşımayan veya bu vizyonu taşıdığı halde gerçekleştiremeyen yöneticiler olabileceği gibi yeni kurulmuş bir işletme, yöneticilerinin tavrına bağlı olarak kurumsal bir anlayışla kurulmuş ve yönetiliyor olabilir. Kurumsallaşma kavramının bu yönü, ortaya çıkan bu sonucun temel sebebi olabilecek kadar güçlü bir yöndür.

Ancak YBS sayısı için p değeri 0,05'in altındadır ve bu durum işletmenin YBS kullanımının, işletmenin faaliyet yılına göre farklılaştığını göstermektedir. Ortalamalara bakıldığında, 1-5 yıldır faaliyette olan işletmeler, ortalama 3,5313 adet YBS uygulaması bulundurmaktadır. 6-10 yıldır faaliyet gösteren işletmelerde ortalama 6,1667' dir. 11 yıl veya daha uzun süredir faaliyette olan işletmeler ise ortalama 7,6250 adet YBS sistemi bulundurmaktadır. Buradan açıça görüleceği üzere faaliyet yılı arttıkça YBS kullanımı artış göstermektedir. Öyleyse, işletme varlı̆̆ını ve faaliyetlerini sürdürdükçe, süreç içinde, YBS sistemlerine daha çok ihtiyaç duymakta ve bu sistemleri daha çok kullanmaktadır, denebilir. Yıllar geçtikçe kaydedilmesi ve işlenmesi istenen verinin çoğalması, işletme operasyonlarının sayısının artması, muhtemel operasyon 
çeşitlendirme hamleleri gibi unsurlar, YBS sistemlerine duyulan ihtiyacın ve YBS kullanımının artışını açıklayan bir gerekçe olabilir.

Tablo 4. Kurumsallaşma ve YBS Sistemlerinin Faaliyet Yılına Göre Durumu

\begin{tabular}{|c|c|c|c|c|c|c|}
\hline & Faaliyet Yilı & Sayı & Ortalama & Standart Sapma & $\mathbf{F}$ & p \\
\hline \multirow{4}{*}{$\begin{array}{l}\text { Kurumsallaşma } \\
\text { düzeyi }\end{array}$} & $1-5 \mathrm{y}$ yl & 32 & 3,3294 & 0,87393 & \multirow{4}{*}{0,648} & \multirow{4}{*}{0,525} \\
\hline & 6-10 yil & 12 & 3,4149 & 0,98499 & & \\
\hline & $\begin{array}{l}11 \text { yıl ve } \\
\text { üzeri }\end{array}$ & 56 & 3,1581 & 0,85589 & & \\
\hline & Toplam & 100 & 3,2438 & 0,87407 & & \\
\hline \multirow[t]{4}{*}{ YBS sayısı } & 1-5 yil & 32 & 3,5313 & 3,49178 & \multirow{4}{*}{5,076} & \multirow{4}{*}{0,008} \\
\hline & 6-10 y1l & 12 & 6,1667 & 5,99747 & & \\
\hline & $\begin{array}{l}11 \text { yil ve } \\
\text { üzeri }\end{array}$ & 56 & 7,6250 & 6,72462 & & \\
\hline & Toplam & 100 & 6,1400 & 6,03194 & & \\
\hline
\end{tabular}

Tablo 5. Kurumsallaşma ve YBS Sistemlerinin Çalışan Kişi Sayısına Göre Durumu

\begin{tabular}{|c|c|c|c|c|c|c|}
\hline & Çalışan sayısı & Say1 & Ortalama & Standart Sapma & $\mathbf{F}$ & $\mathrm{p}$ \\
\hline \multirow{5}{*}{$\begin{array}{l}\text { Kurumsallaşma } \\
\text { düzeyi }\end{array}$} & 1-9 kişi & 29 & 3,6006 & 0,68865 & \multirow{5}{*}{3,588} & \multirow{5}{*}{0,017} \\
\hline & 10-49 kişi & 27 & 2,9159 & 0,90469 & & \\
\hline & 50-249 kişi & 21 & 3,0536 & 1,06314 & & \\
\hline & 250 ve üstü & 23 & 3,3524 & 0,70215 & & \\
\hline & Toplam & 100 & 3,2438 & 0,87407 & & \\
\hline \multirow[t]{5}{*}{ YBS sayısı } & 1-9 kişi & 29 & 4,0690 & 4,92755 & \multirow{5}{*}{9,888} & \multirow{5}{*}{0,000} \\
\hline & 10-49 kişi & 27 & 3,8519 & 3,72831 & & \\
\hline & 50-249 kişi & 21 & 6,4286 & 4,86386 & & \\
\hline & 250 ve üstü & 23 & 11,1739 & 7,49941 & & \\
\hline & Toplam & 100 & 6,1400 & 6,03194 & & \\
\hline
\end{tabular}

Kurumsallaşma ve YBS sistemlerinin çalışan kişi sayısına göre durumunu tespit amaçlı yapılan tek yönlü Anova analizinin sonuçlarının gösterildiği Tablo 5'e göre hem kurumsallaşma hem de YBS sayısı için p değerleri 0,05'in altındadır. Bunun anlamı, hem kurumsallaşma düzeyinin hem de YBS kullanımının çalışan sayısına göre anlamlı şekilde farklılaşmasıdır.

Kurumsallaşma düzeyi için çalışan sayıları ve ortalamalara bakıldığında, kurumsallaşma düzeyi en yüksek olan grubun en az çalışana sahip grup (1-9 kişi) olması dikkat çekicidir. Bunun nedeni, bir işletmede çalışan sayısı az iken işletmeyi yönetmenin, bir kurum kültürü oluşturmanın ve kurumsal uygulamaları yerleştirmenin daha kolay olması fikrinde yatıyor olabilir. Buna göre çalışan sayısı arttıkça, bu faaliyetlerin daha karmaşık bir hal aldığı ve zorlaştığı da söylenebilir. Bir işletmede çalışan sayısının artması, işletme faaliyetlerinin sayıca artması ve dolayısıyla karmaşıklaşmasının bir sonucu olduğundan, çalışan sayısı arttıkça işletmenin idaresinin zorlaşması ve kurumsallaşma düzeyinin düşmesi mantıklı görünmektedir.

Öte yandan diğer üç gruba bakıldığında, çalışan sayısı arttıkça kurumsallaşma düzeynin de yükseldiği görülmektedir. Buradan hareketle, çalışan sayısının artmasının, işletmenin 
kurumsallık düzeyini de yükselttiği yorumu yapılabilir. Bunun sebebi, çalışan sayısının artması sonucu işletme yönetiminin zor ve karmaşık bir hale gelmesi ve bu zorluğun üstesinden gelebilmek için işletmenin kurumsallaşmaya daha çok ihtiyaç duyarak kurumsallaşma düzeyini yüksetlmesi olabilir.

Çalışan sayısı ve kurumsallaşma düzeyine ilişkin yukarıdaki iki yorum çelişik gibi görünmektedir ancak bu durum kurumsallaşma düzeyinin belli bir çalışan sayısını geçtikten sonra düşüp sonra yavaş yavaş yükselmesi ile açıklanabilir. Az sayıda çalışanı olan işletmeler, çalışan sayısını arttırmaları gereken bir eşik noktasına geldiklerinde işletmenin çehresi değişiyor, mevcut kurumsallık uygulamaları bir anda yetersiz kalıyor veya geçersiz hale geliyor ve bir yeniden yapılanma sürecine ihtiyaç duyuyor olabilirler. Bu fikir, ayrı bir çalışma konusu olmaya ve test edilmeye değer görünmektedir.

YBS kısmına bakıldığında 1-9 çalışanı olan işletmelerle, 10-49 çalışanı olan işletmelerin hemen hemen aynı sayıda YBS sistemi kullanmakta oldukları (4 adet) görülmektedir. 50-249 çalışanı olan işletmeler yaklaşık altı 6 YBS sistemine sahipken, 250 veya daha fazla çalışanı olan işletmeler ise ortalama 11 adet YBS sistemi kullanmaktadır. Gruplar arasındaki farklara bakıldığında çok büyük işletmelerin (250 ve üstü çalışan) YBS sistemlerine çok önem verdiği görülmektedir. Bu durum, çok sayıda çalışanı olan işletmelerin YBS sistemlerine daha fazla ihtiyaç duymasından kaynaklanıyor olabilir. Çünkü bir işletmenin çok sayıda çalışanı olması, o işletmenin faaliyetlerinin yoğun, geniş bir alana yayılmış veya kompleks faaliyetler olduğunu göstermektedir. Bu durumda da işletme, faaliyetlerine ilişkin verileri toplamak, işlemek, bilgiye dönüştürmek, kaydetmek, önemli karar süreçlerinde verilerden üretilmiş bilgileri kullanmak konularında YBS uygulamalarının avantajlarını göz ardı edemez. YBS kullanmadan karmaşık süreçlere ilişkin bu faaliyetleri gerçekleştirmesi mümkün de değildir. İşletme faaliyetleri dışında çok sayıda çalışanın ücret, mesai, izin vb. pek çok bilgisini tutup işlemek bile başlı başına YBS uygulamaları kullanmayı bu işletmelerde gerekli kılar. Dolayısıyla çok sayıda çalışanı olan işletmelerin YBS kullanımına daha fazla önem vermesi kaçınılmaz görünmektedir.

Tablo 6'da görüldügü̈ üzere, çalışmada ortaklık yapısı tek ortaklı işletme, çok ortaklı işletme ve aile işletmesi seçenekleri kapsamında ele alınmıştır. Kurumsallaşma ve YBS sistemlerinin ortaklık yapısına göre durumunu tespit amaçlı yapılan tek yönlü Anova testinin sonuçlarının gösterildiği Tablo 6'ya göre kurumsallaşma için p değeri $0,05^{\prime}$ in altında olup kurumsallaşma düzeyinin ortaklık yapısına göre istatistiksel olarak farklılaştığını ifade etmektedir. Kurumsallaşma düzey ortalamalarına bakıldığında tek ortaklı işletmelerin kurumsallaşma düzeyinin (5 üzerinden 3,4) çok ortaklı işletmelerin kurumsallaşma düzeyinden (5 üzerinden 3,2) yüksek olduğu görülmektedir. Aradaki fark fazla değildir. Ancak yine de bu durumu yorumlayacak olursak, ortaklar arasındaki fikir farklılıklarının işletmeye olası yansımaları, bu durumu açıklayabilir. Aile işletmelerinde ise kurumsallaşma düzeyi diğer iki gruba göre dikkate değer ölçüde aşağıdadır (5 üzerinden 2,7). Aile işletmelerinde görülen kurumsallaşma anlayışına uymayan pek çok uygulama bu durumu fazlasıyla açıklar.

Tablo 6' da, YBS sayısı için p değerinin 0,05 değerinden büyük olduğu görülmektedir. Dolayısıyla çalışma verisine göre işletmelerdeki YBS kullanımının, ortaklık yapısıyla bir ilişkisi olmadığı sonucuna varılabilir. Bu durum, YBS'nin yönetimi destekleyen bilgiler sunmakla sinırlı sistemler olmasından kaynaklı görünmektedir. İşletmede kimlerin, hangi miktarda hak ve pay sahibi olduğu YBS uygulamalarının konusu değildir. YBS uygulamaları bu konuyu dikkate almaz, almaları da gerekmez. 
Tablo 6. Kurumsallaşma ve YBS Sistemlerinin Ortaklık Yapısına Göre Durumu

\begin{tabular}{|c|c|c|c|c|c|c|}
\hline & Ortaklık yapısı & Sayı & Ortalama & $\begin{array}{c}\text { Standart } \\
\text { Sapma }\end{array}$ & $\mathbf{F}$ & p \\
\hline \multirow{4}{*}{$\begin{array}{l}\text { Kurumsallaşma } \\
\text { düzeyi }\end{array}$} & Tek ortaklı işletme & 35 & 3,4506 & 0,74536 & \multirow{4}{*}{3,983} & \multirow{4}{*}{0,022} \\
\hline & $\begin{array}{ll}\text { Çok } & \text { ortaklı } \\
\text { işletme } & \\
\end{array}$ & 45 & 3,2856 & 0,79302 & & \\
\hline & Aile işletmesi & 20 & 2,7875 & 1,10826 & & \\
\hline & Toplam & 100 & 3,2438 & 0,87407 & & \\
\hline \multirow[t]{4}{*}{ YBS say1S1 } & Tek ortaklı işletme & 35 & 5,5143 & 5,21520 & \multirow{4}{*}{0,439} & \multirow{4}{*}{0,646} \\
\hline & $\begin{array}{ll}\text { Çok } & \text { ortaklı } \\
\text { işletme } & \\
\end{array}$ & 45 & 6,2000 & 6,39815 & & \\
\hline & Aile işletmesi & 20 & 7,1000 & 6,66412 & & \\
\hline & Toplam & 100 & 6,1400 & 6,03194 & & \\
\hline
\end{tabular}

$\mathrm{Bu}$ analizler yanında, çalışmanın asıl konusu olan kurumsallaşma ve YBS ilişkisinin tespitine yönelik olarak işletmelere ait anket verilerinin ortaya koyduğu kurumsallaşma düzeyleri ile YBS sayıları arasında korelasyon analizi yapılmıştır.

Tablo 7. Kurumsallaşma ve YBS Sistemlerinin İlişkisi

\begin{tabular}{|l|l|c|c|}
\hline & & Kurumsallaşma düzeyi & YBS Sayıs \\
\hline Kurumsallaşma düzeyi & $\mathbf{r}$ & 1 & $0,299^{* *}$ \\
\cline { 2 - 4 } & $\mathbf{p}$ & & 0,002 \\
\cline { 2 - 4 } & $\mathbf{n}$ & 100 & 100 \\
\hline \multirow{3}{*}{ YBS sayısı } & $\mathbf{r}$ & $0,299^{* *}$ & 1 \\
\cline { 2 - 4 } & $\mathbf{p}$ & 0,002 & 19 \\
\cline { 2 - 4 } & $\mathbf{n}$ & 19 & \\
\hline
\end{tabular}

**. Korelasyon 0,01 düzeyinde (2 yönlü) anlamlıdır.

Tablo 7'de görüldüğg̈ gibi $r$ değeri 0,299 olup 0,2 ile 0,4 arasında bir değerdedir. Bu da iki değişken arasında zayıf bir korelasyon olduğunu ifade eder. İki değişken arasında istatistiksel olarak anlamlı ve direk yönlü ancak zayıf bir ilişki belirlenmiştir. Buna göre, işletmelerin kurumsallaşma düzeyinin artmasıyla o işletmelerdeki YBS uygulamalarının da artmakta olduğu, kurumsallaşma düzeyinin azalmasıyla YBS uygulamalarının da azaldığı söylenebilir. Ancak bu ilişki, araştırma öncesinde beklendiği kadar güçlü değildir. Kurumsallaşma ve YBS arasında tespit edilen bu ilişkinin sebepleri; hem kurumsallaşmanın hem de YBS'nin işletmede belli standartları desteklemesi, işletmenin büyümesinin hem kurumsallaşma hem de YBS'ye olan ihtiyacı arttırması ve kurumsallaşma ve YBS'nin benzer yönetim anlayışları tarafından desteklenmesi olabilir.

Öncelikle hem kurumsallaşma hem de YBS işletmede belli standartların olmasını destekler. Kurumsallaşma, zaten temelde, işletmenin belli kural ve standartlara göre yönetilme anlayışını ifade etmektedir. Yönetim bilişim sistemleri de bilgisayar destekli ve yazılım tabanlı sistemler olduğu için belli çalışma yöntemleri ve kalıpları ile sınırlıdır. Bu çalışma biçimi de bugünden yarına değişen işletme uygulamalarıyla örtüşmez; belli bir düzen gerektirir. İşletmenin işleyişi ve faaliyet tarzı belli standartlara uygun olmalıdır ki YBS uygulamaları da işletmedeki bu düzene 
uygun şekilde verileri toplasın, işlesin, kaydetsin ve bilgi üreterek yönetime sunsun. YBS, bir gün belli bir alanda, bir gün başka bir alanda veri toplayarak işlevini sürdüremez. YBS, belli bir esnekliğe izin vermesine rağmen düzensiz ve fazla değişken bir işleyiş̧i desteklemez. Zaten böyle bir işletme de varlığını uzun süre devam ettiremez.

Bir işletmenin büyümesi de kurumsallaşmaya ve YBS'ye duyulan ihtiyacı arttırıyor olabilir. Çünkü işletme büyüdükçe işletmenin faaliyetleri, faaliyet alanları, çalışan sayısı, çevre ile olan ilişkileri artmakta, kararların önemi ve etkisi ile olası hata ve düzensizliklerin bedeli de ağırlaşmaktadır. Bu durumun işletmenin günü kurtaran bir yapıda devam etmesini imkansız kılacağı ve kurumsallaşma düzeyinin artmasını gerektireceği söylenebilir. Söz konusu durum, aynı zamanda YBS'nin işletmedeki etkinliğinin de artmasını sağlayacaktır; çünkü, artan tüm bu işleri takip edebilmek ve zorlaşan koşullarda karar verebilmek için işletme doğal olarak YBS uygulamaları kullanımına yönelmek durumundadır.

Kurumsallaşma yaklaşımı ve YBS uygulamalarının benzer yönetim anlayışları tarafından desteklendiği söylenebilir. Çünkü her iki unsur da belli açılardan işletmeye benzer katkılarda bulunur. Günümüzün karmaşık ve değişken iş dünyasında ayakta kalabilmek, verimlilik sağlamak, doğru kararlar verebilmek, rekabet gücünü arttırmak ve sürdürülebilirlik için kurumsal bir yapıya ihtiyaç vardır. Kurumsal yapı, işletme içinde standartlara ve uzmanlığa dayalı olarak adaleti sağlar, işletmenin karar süreçlerine çalışanları dahil eder. Böylece işletmeyi daha çok benimseyen çalışanların işletmeye zor zamanlarda sahip çıkmasını; hakkını aldığını ve haksızlığa uğramadığını bilen çalışanın yüksek performans göstererek verimliliği arttırmasını destekler. Etkin bir iletişim sistemine sahip ve iç denetim faaliyetlerini yerine getiren kurumsal yapı, zaman ve enerji kayıplarını en aza indirerek; yanlış veya eksik uygulamaları tespit edip düzelterek verimliliği arttırır. Bünyesindeki uzman ve profesyoneller ile en doğru kararların alınmasını sağlar. Stratejik bir plan ile geleceğe doğru emin adımlarla ilerleyen yüksek derecede kurumsal işletmeler, sözü edilen tüm diğer faktörlerle birlikte yüksek rekabet gücüne sahip olurken sürdürülebilirliklerini de büyük ölçüde garantiler. Yönetim bilişim sistemleri de gerek çalışanlara yönelik suistimale kapalı niceliksel bir uzmanlık ve performans sistemi sunarak, gerek kararlar alınırken şeffaf ve ortak bir platform sunarak, gerek tuttuğu kayıtlar ile iç denetim kapsamında hedeflerin gerçekleşme oranlarını ortaya koyarak, gerekse sunduğu yönetsel raporlarla tüm bu süreçlere ciddi katkılar sağlar. Dolayısıyla işletmesini geleceğe güçlü ve güvenle taşımak isteyen, sağlam bir vizyona sahip; verimlilik, rekabet gücü, doğru kararlar vermek ve sürdürülebilirlik konularını önemseyen yöneticilerin hem kurumsallaşma hem de YBS kullanımı konusunda gayret göstereceği söylenebilir.

\section{SONUÇ VE ÖNERİLER}

Kurumsallaşma, günümüzde işletmeler için önemli bir kavram ve süreç durumundadır. Yönetim bilişim sistemleri de benzer şekilde günümüzde işletmeler için önemli durumdadır ve bu sistemlerin önemi, dijitalleşmekte olan dünyada daha da artmaktadır. Bu çalışmada, işletmeler için önemli bu iki kavram birlikte ele alınmış ve bir ilişkileri olup olmadığı araştırılmıştır. Çalışma kapsamında işletmeler arasında herhangi bir ayrım yapılmaksızın, Ankara'da 100 adet işletmenin yetkililerine anket uygulanmış olup elde edilen veriler istatistiksel yöntemlerle analiz edilmiş ve sonuçlar yorumlanmıştır. Söz konusu anket; demografik sorular, kurumsallaşma düzeyini ölçen sorular ve işletmenin kullandığ yönetim bilişim sistemlerini tespit eden sorulardan oluşan üç bölüm olarak uygulanmıştır. Anket ile elde edilen verilerin analizi sonucu elde edilen bulgulara ilişkin çeşitli yorumlar yapılmıştır. 
İşletmelerin hizmet sektöründe veya üretim sektöründe olmaları kurumsallaşma düzeylerini etkilememektedir. Bu durum benzer şekilde işletmelerin kullandığ ${ }_{1}$ YBS sistemleriyle de ilişkili değildir. $O$ halde, kurumsallaşma ve yönetim bilişim sistemleri, bir işletmeyi sektörel farklılıkların ötesinde etkileyen unsurlardır. Buradan hareketle, işletmelere, kurumsallaşma ve YBS kullanımı konusundaki yaklaşım, bakış açısı, tavır ve gayretlerini sektörel değişkenlere takılmadan, daha geniş bir ölçekte değerlendirmeleri önerilmektedir. Ayrıca, bu konuda daha iyi bir anlayış yakalamak için araştırmacılar da daha detaylı sektörel bir ayrım yaparak ve daha farklı çalışma grupları ile kurumsallaşma ve YBS kullanımının farklılaşıp farklılaşmadığını araştırabilirler.

Kurumsallaşma düzeyinin, işletmenin faaliyet yılıyla bir ilişkisi olmadığı da gözlemlenmiştir. Dolayısıyla, eski veya köklü işletmeler daha kurumsaldır şeklindeki bir yorum sağlıklı olmayacaktır. Benzer şekilde, genç işletmeler kurumsallaşmaya daha çok önem verir gibi bir düşünce de dayanaksızdır. Kurumsallaşma, işletmenin yaşından bağımsız, temel bir anlayış ve yaklaşım biçimidir. Dolayısıyla, işletmelere, kurumsallaşma ihtiyaçlarını tespit ederken işletmenin yaşını bir kriter olarak ele almamaları önerilmektedir.

YBS kullanımının ise işletmenin faaliyet yılıyla bir ilişki olduğu gözlemlenmiştir. Faaliyet yılı arttıkça YBS kullanımı artmaktadır. İşletme operasyonlarının sayısının zamanla artması ve muhtemel operasyon çeşitlendirme hamleleri gibi etkenlerin, kaydedilmesi ve işlenmesi gerekli veriyi çoğaltacak olmasının bu durumu doğurmuş olabileceği düşünülmektedir. Bu da süreç içinde işletmelerin YBS'ye duyduğu ihtiyacın artışı anlamına gelir. Bu sonuçlardan hareketle, işletmelere, gerek kurulma aşamasında, gerekse faaliyetlerini devam ettirirken, gelecekte YBS uygulamalarına duyacakları ihtiyacın artacağı bilinciyle planlama yapmaları ve hareket etmeleri tavsiye edilmektedir. Ayrıca, YBS kullanımlarının yeterli düzeyde olup olmadığını değerlendirirken de işletmenin yaşını göz önünde bulundurabilirler.

Çalışmadan çıkan bir başka sonuç, işletmelerde kurumsallaşma düzeyinin çalışan sayısı ile ilgili olmasıdır. Çalışan sayısı arttıkça kurumsallaşma düzeyi önce düşmekte sonra yavaş yavaş yükselmektedir. Yükselmeden önceki bu düşüşün, işletmelerin büyürken yaşadığı geçiş evresinin bir özelliği olabileceği düşünülmektedir. Bu geçiş döneminde işletmedeki mevcut kurumsallık uygulamaları bir anda yetersiz kalıyor veya geçersiz hale geliyor ve işletme, bir yeniden yapılanma sürecine ihtiyaç duyuyor olabilir. Bu konu, ayrıca çalışmaya değer görülmektedir. Bu noktada araştırmacılara, konuyu daha fazla aydınlatmak için yeni araştırmalar yapmaları önerilmektedir. Ayrıca, çalışan sayısı az olan ve büyümeye hazırlanan işletmelerin de belli bir eşik süreci geçireceklerinin bilincinde olarak kurumsallaşma uygulamalarını gözden geçirmeleri ve geleceğe yönelik adımlar atmaları kendileri için son derece faydalı olabilir.

Çalışan sayısının YBS kullanımında da bir farklılaşmaya sebep olduğu, çalışan sayısının artmasının YBS kullanımını da arttırdığı görülmüştür. Özellikle çok büyük işletmelerin YBS kullanımına verdiği önem dikkat çekmektedir. Dolayısıyla, yine çalışan sayısını arttırmayı planlayan işletmelere, YBS uygulamalarına duyacakları ihtiyacın artacağı bilinciyle hazırlıklar yapmaları önerilmektedir. Çalışan sayısı az olan işletmelerin ise fazla miktarda YBS uygulamaları kullanıyorlarsa bu uygulamaların gerekliliğini ve işletmeye katkılarını gözden geçirmeleri faydalı olabilir. Gereksiz bir kullanım söz konusu ise bu alanda sadeleşmeye giderek enerji, zaman ve para tasarrufu sağlayabilirler. Bu işletmeler, ayrıca, YBS ihtiyaçlarını analiz ederken çok sayıda çalışanı olan işletmeleri baz alarak hareket etmemelidirler. Çünkü çalışan sayısı fazla olan işletmelere göre bu sistemlere daha az ihtiyaç duymaktadırlar. 
Ortaklık yapısı da kurumsallaşma düzeyi ile ilişkili olan bir başka unsurdur. Araştırmaya göre tek ortaklı işletmeler, çok ortaklı işletmelerden daha kurumsaldır. Aile işletmeleri ise en az kurumsal işletmeler olarak göze çarpmaktadır. Bu noktada kurumsallık düzeyini arttırmak için çok ortaklı işletmelerin, yönetime dair anlaşmazlıkları en aza indirecek ve anlaşmazlık durumlarında en pratik ve sağlıklı çözümleri bulacak tedbirler üzerinde çalışmaları ve aile işletmelerinin de kurumsallaşmanın önemini idrak ederek kurumsallaşmaya özel bir önem vermeleri önerilir. Aile işletmeleri geleceğe güvenle bakabilmek istiyorlarsa kurumsallaşmanın kendileri için önemini iyi kavramalıdırlar.

Çalışmadan çıkan sonuçlar, ortaklık yapısının YBS kullanımı ile bir ilişkisinin olmadı̆̆ını göstermektedir. Bu sonuç, YBS uygulamalarının temel işlevi olan işletme yönetimini destekleyici bilgiler sunma çerçevesine uygundur. İşletmelere, ortaklık yapısına ilişkin karar ve eylemlerinde YBS uygulamalarını bir şekilde kullanmayı denememeleri önerilir. Çünkü bu sonuçsuz bir çaba olacaktır.

Çalışmanın ana sonucu ise işletmelerde kurumsallaşma ve YBS kullanımı arasında zayıf bir ilişkinin varlığının saptanmıştır. Kurumsallaşma düzeyi ve YBS kullanımı birlikte artmakta veya azalmaktadır. Bu çalışmanın sonucu olarak ortaya çıkan ilişkinin, farklı araştırmacılar tarafından da farklı örneklem kümeleri veya farklı yöntemler kullanılarak araştırılması, bu çalışmada ulaşılan sonucu pekiştirmek veya farklı bir durum söz konusu ise bunu ortaya koymak açısından önemli olacaktır. Ayrıca yeni çalışmalar, söz konusu ilişkiyi farklı yönleriyle ele alma ve bu ilişkinin özelliklerini daha iyi anlama konusunda da faydalı olacaktır. Yeni çalışmalar, YBS kullanımının kurumsallaşmayla ilişkisinin belki daha ileri boyutlarda olduğunu gösterecek, YBS kullanımının da bir kurumsallaşma göstergesi olarak kabul edilip edilemeyeceği konusunda aydınlatıcı olacaktır. Özellikle giderek dijitalleşmekte ve dönüşmekte olan günümüz iş dünyasında YBS kullanımının bu göstergeler arasındaki yerini alması, belki bugün değil ancak gelecekte gerçekleşmesi olası bir durumdur. Son olarak, çalışmanın sonuçlarından hareketle kurumsallaşmak isteyen işletmelerin yönetim bilişim sistemlerine ve bu sistemleri kullanmaya önem vermeleri tavsiye edilmektedir.

\section{KAYNAKLAR}

Al-Mamary, Y. H. S., Shamsuddin, A. and Nor Aziati, A. H. (2014). The Role of Different Types of Information Systems in Business Organizations: A Review. International Journal of Research, 1(7), 1279-1286.

Akyol, C. ve Zengin, B. (2014). Turizmde Kurumsallaşma Sorunları, Aile İşletmeleri Örneği. Akademik Bakış Dergisi, (41), 1-22.

Anameriç, H. (2005). Yönetim Bilgi Sistemlerinin Yönetim Fonksiyonları Üzerine Etkisi. Ankara Üniversitesi Dil ve Tarih-Coğrafya Fakültesi Dergisi, 45(2), 25-43.

Apaydın, F. (2008). Kurumsallaşmanın Küçük ve Orta Ölçekli İşletmelerin Performansına Etkileri. ZKÜ Sosyal Bilimler Dergisi, 4(7), 121-145.

Aylan, S. ve Koç, H. (2017). İşletmelerin Kurumsallaşma Kriterlerinin Belirlenmesine Yönelik Bir Ölçek Geliştirme Çalışması. Gazi Üniversitesi İktisadi ve İdari Bilimler Fakültesi Dergisi, 19(2), 564585. 
Cevher, E. (2014). Kurumsallaşma Küçük İşletmeler için Bir Çözüm müdür Yoksa Yok Olma Nedeni midir?. Uluslararası Sosyal Araştırmalar Dergisi, 7(32), 583-593.

Demir, C. ve Yılmaz M. K. (2010). Stratejik Planlama Süreci ve Örgütler Açısından Önemi. Dokuz Eylül Üniversitesi İktisadi ve İdari Bilimler Fakültesi Dergisi, 25(1), 69-88.

Derdiman, R. C. ve Uysal, Y. (2014). Türk Kamu Yönetiminde Yetki Devri. U.Ü. Fen-Edebiyat Fakültesi Sosyal Bilimler Dergisi, 2(27), 251-277.

Derin, Ş. ve Şimşek Ilkım, N. (2016). Kurumsallaşma Çabalarının Lider-Üye Etkileşimiyle İlişkisi: Malatya Turgut Özal Tıp Merkezinde (Merkezi Yöneticileri Üzerine) Bir İnceleme. Birey ve Toplum, 6(12), 23-48.

Emhan, A. (2007). Karar Verme Süreci ve Bu Süreçte Bilişim Sistemlerinin Kullanılması. Elektronik Sosyal Bilimler Dergisi, 6(21), 212-224.

http://www.guvenlicalisma.org/19687-2013-ten-bugune-ankara-da-en-az-300-isci-yasaminiyitirdi-ankara-is> [Erişim Tarihi: 04.04.2019].

https://www.tmmob.org.tr/icerik/mmo-kucuk-ve-orta-olcekli-sanayi-isletmeleri-raporuaciklandi [Erişim Tarihi: 11.12.2019].

Israel, G.D. (2013). Determining Sample Size. Institute of Food and Agricultural Sciences (IFAS), University of Florida, PEOD-6, 1-5.

İşçi, E., Bal Taştan, S. ve Kozal, M. A. (2013). Örgütlerde Kurumsallaşma Düzeyinin Nepotizm Üzerine Etkisinin İncelenmesi: Hastane Çalışanları Örneği. Siyaset, Ekonomi ve Yönetim Araştırmaları Dergisi, 1(3), 61-83.

Kalkan, N. (2018). Küreselleşme Gücüne Karşllı Aile İşletmelerinde Profesyonel Yönetim. Bankacılık ve Finansal Araştırmalar Dergisi, 5(2), 1-14.

Kalıpsız, O. (1989). Yönetim Bilişim Sistemi. İstanbul Üniversitesi Orman Fakültesi Dergisi, Seri B, 39(1), 101-109.

Karavardar, G. (2011). Aile İşletmelerinde Kurumsallaşma, Yetki Devri ve Belirsizliğe Tolerans. Kırıkkale Üniversitesi Sosyal Bilimler Dergisi, 1(1), 157-179.

Laudon, K. C. and Laudon, J. P. (2012). Management Information Systems: Managing the Digital Firm (Twelfth Edition). United States of America: Prentice Hall.

Miman, M., Yoğun, A. E. ve Önel, Y. E. (2016). Yönetim Bilgi Sistemleri Kullanım Özellikleri Arasındaki İlişkiler: Lojistik Sektörü Üzerine Bir Çalışma. Akademik Bakış Dergisi, (54), 161-173.

Narmambetova, A., Avci, S. B. ve Barlı, Ö. (2016). Kurumsallaşma Göstergelerinin Doğrulayıcı Faktör Analizi ile İncelenmesi ve Kurumsallaşma Algılarını Farklılaştıran Etmenlerin Belirlenmesi: Kırgızistan Örneği. Bartın Üniversitesi İ.İ.B.F. Dergisi, 7(13), 186-207.

Nişanc1, Z. N., Oğrak, A., Kaya, A., Özçelik, S. ve Düzgün, H. A. (2015). Kurumsallaşma, Kurumsal Kuram ve Kurumsal Yönetim: Kavramlar Arası Farklılıklar ve Biçimselleşme, (Editörler) Güneş, R., Çukacı, Y. C. ve Deste, M.: Turgut Özal Uluslararası Ekonomi ve Siyaset Kongresi - III Kurumsal Yönetim ve Kurumsallaşma Bildiriler Kitabı içinde (ss.174-187) Malatya: İnönü Üniversitesi. 
Saral Kobal, K. E. ve Aşkun Yıldırım, O. B. (2016). Aile İşletmelerinin Kurumsallaşma Sürecinde İkinci Kuşağın Yaşadığı Sorunlar Üzerine Bir Araştırma. Marmara Üniversitesi Öneri Dergisi, 12(46), 97-120.

Singh, A. S. and Masuku, M. B. (2014). Sampling Techniques \& Determination of Sample Size in Applied Statistics Research: An Overview. International Journal of Economics, Commerce and Management, 2(11), 1-22.

Surwade, D. (2016). Management Information Systems and Its Application in Business Decision Making. International Journal on Recent and Innovation Trends in Computing and Communication, 4(8), 201-203.

Şahman, İ., Tengilimoğlu, D. ve Işık, O. (2008). Özel Hastanelerde Yönetimin Profesyonelleşmesinin, Kurumsallaşma Süreci Üzerindeki Etkisini Belirlemeye Yönelik Alan Çalışması. Gazi Üniversitesi İktisadi ve İdari Bilimler Fakültesi Dergisi, 10(2), 1-23.

Tanyıldızı, İ. ve Demir, Ö. (2019). Sağlık Kurumlarında Yalın Yönetim. Fırat Üniversitesi İ̈BF Uluslararası İktisadi ve İdari Bilimler Dergisi, 3(1), 13-40.

Tinaztepe, C. (2012). Örgüt İçi Etkin İletişimin Örgütsel Sinizme Etkisi. Organizasyon ve Yönetim Bilimleri Dergisi, 4(1), 53-63.

Türkoğlu, N. ve Çizel, B. (2016). Kurumsallaşma ve Rekabet Gücü İlişkisi Üzerine Ampirik Bir Çalışma. Bilgi Sosyal Bilimler Dergisi, (2), 156-184.

Ural, T. ve Balıkçıoğlu, B. (2004). Aile Şirketlerinde Kurumsallaşma ile Şirket Sahibinin Kültürel Değerleri Arasındaki İlişki: Antakya ve Kayseri Örneği, (Editör) Koçel, T.: 1. Aile İşletmeleri Kongresi Kongre Kitabı içinde (ss.534-546) İstanbul: İstanbul Kültür Üniversitesi.

Yazıcıoğlu, İ. ve Koç, H. (2009). Aile İşletmelerinin Kurumsallaşma Düzeylerinin Belirlenmesine Yönelik Karşılaştırmalı Bir Araştırma. Selçuk Üniversitesi Sosyal Bilimler Enstitüsü Dergisi, (21), 497507.

Yenice, S. ve Dölen, Y. (2013). İmkb’de İşlem Gören Firmaların Kurumsal Yönetim İlkelerine Uyumunun Firma Değeri Üzerindeki Etkisi. Uluslararası Yönetim İktisat ve İşletme Dergisi, 9(19), 199-214.

Yıldırım, K. E. (2019). Profesyonel Yöneticiliğin Kamu Yönetiminde Uygulanabilirliği. Kafkas Üniversitesi İktisadi ve İdari Bilimler Fakültesi Dergisi, 10(19), 576-589. 